\title{
Challenges of the Digital Era Development in Relation to Tax Systems. Taxing the Digital Economy
}

\author{
Robert-Aurelian ŞOVA, Full Professor, PhD., Adriana Florina POPA, Associate Professor, PhD.
}

Bucharest University of Economic Studies

\begin{abstract}
The digital era provides new opportunities for innovation and economic growth. Fiscally, it creates opportunities for tax administrations to reduce tax evasion. On the other hand, the changing business models create international pressure on the tax system. The current requirements were established at the beginning of the 20th century for traditional companies, based on the principle of taxing profits where value is created. For digital activities, physical presence is no longer necessary in order to provide services. Thus, two major questions arise: Where do we tax?, in the case of a company with limited or no physical presence, and What do we tax?, in the case of a digital business plan based on knowledge, data and intangible assets.
\end{abstract}

Key terms: digital era, tax system, taxation, digital services

JEL Classification: H87, K34, O33, Q55

To cite this article: Robert-Aurelian Şova, Adriana Florina Popa, Challenges of the Digital Era Development in Relation to Tax Systems. Taxing the Digital Economy, CECCAR Business Review, №3/2020, pp. 65-70, DOI: http://dx.doi.org/10.37945/ cbr.2020.03.07

The digital economy poses a challenge for all our tax regimes (as stated by Donald Tusk, the president of the European Council, after the meeting with the EU leaders that took place in March 2018), as its rapid development lead to the conclusion that international tax rules are not adequately tailored. One of the current objectives of the European Union is the optimization of the Member States' tax systems of to ensure they can meet the challenges of the digital era.

Deficiencies are mainly caused by the fact that tax rules are made for companies with a physical presence, which often is the basis on which a state is entitled to tax an entity's profits.

Let us take the example of the Romanian regulation, namely article 12 a) of the Tax Code, according to which revenues attributable to a permanent establishment in Romania are considered to be obtained in our country, and therefore they are implicitly taxed in this state, regardless of whether they are received in Romania or a different country. In this context, the permanent establishment is a place in which a non-resident carries on their business, wholly or partly, either directly or through a dependent agent.

According to this regulation, the phrase "place in which a non-resident taxpayer carries on their business", covers any kind of buildings, equipment or machines used by a non-resident to carry on business, whether they are used exclusively for this purpose or not. A place of business exists even if a non-resident taxpayer only has a space at their disposal, as buildings are not required to carry on business. It does not matter whether the buildings, equipment or machines are owned, rented or otherwise at their disposal. A place of business can be a market stall, or in the building of a different company, if the non-resident has permanent access to the building or to parts of it.

The definition of a permanent establishment takes into account the comments from article 5 - Permanent establishment in the Model Tax Convention on Income and on Capital of the Organisation for Economic Cooperation and Development. 
If we consider the income tax from 2016, for instance, foreign legal entities established and organised in accordance with the laws of a different country are subject to taxation when they carry on business, wholly or partly, through a permanent establishment in Romania, since the beginning of that establishment's activity. This category includes companies, foundations, associations, organisations and any similar entities, according to paragraph 1 (2) of the Methodological Norms for the application of title II - Income tax, Chapter I - General requirements, Section 1 - Taxpayers, article 13 (1) b) of the Tax Code from 6 January 2016. Virtually, it is possible for a company that is a resident in one state to generate significant revenues in another state, where it does not need a physical presence, paying an insignificant or no income tax.

Digital companies create added value from the online environment, with no physical presence in the source country. As a result, their income is not subject to taxation or, possibly, is taxed in the wrong country. This fact lead to the EU's intention to introduce a fair tax system for all companies, regardless of their size or whether they are involved in the digital economy or not.

Additionally, another particularity is the fact that these digital companies obtain revenues mainly from difficult to assess intangible assets, which also leads to their not being taxed.

Let us consider, for example, the case of Starbucks, a highly successful company with an increasing number of shops and a significant presence in the United Kingdom. However, throughout the whole period it carried on business in the United Kingdom, the company has only paid income tax once. This was possible due to the use of a series of legal tax avoidance practices, such as transfer prices, royalty payments, interest expenses and others, all of which resulted in the profit shifting towards branches in low tax jurisdictions. These tax avoidance practices were, for that matter, commonplace among international companies (Campbell and Helleloid, 2016).

As an international response, OECD and G20 have developed the BEPS plan, comprising 15 actions related to tax base erosion and profit shifting, which cover common tax avoidance practices, the use of which can result in aggressive tax planning, a phenomenon generated by the harmful competition between tax jurisdictions. The aim of these actions was to ensure that profits are taxed where economic activities that generate income take place and where value is created.

Some people believe that this plan is not a viable solution. An alternative approach, known as unitary taxation, which treats each group of companies as a single economic entity, may solve all the aforementioned issues. For this purpose, the assumption is that no sales, costs or profits can exist if a company does not carry out transactions with an external party. Thus, all intergroup movements with an effect on income are cancelled.

Continuing the policy adopted by the OECD, the European Commission added on its agenda an anti-tax avoidance package for a fairer, more simple and effective taxation for EU corporations.

With regard to the aforementioned practices, the European Commission conducted a study in 2013 about the tax practices of some European countries for multinational companies. Facebook, Amazon and Google are companies that have been identified by the European Commission as having the following thing in common: they all pay lower taxes in the EU Member States in which they carry on business. Essentially, in their case, but not only, digitalization enables access to markets in jurisdictions where they can have little or no physical presence (Spirescu and Blatac, 2018).

\section{? Taxing the digital economy}

In the context of insufficient regulation in the digital area, on 19 October, 2017, the European Council discussed the necessary measures for building a strong, successful digital economy (the meeting report of the European Council from 19 October 2017). On this occasion, there was a call for a fair and efficient tax system that is appropriate for the digital era.

The sequence of actions taken by the European Union is presented below.

\section{$\checkmark 4$ July 2017: The meeting of the High Level Working Group of the ECOFIN regarding tax issues}

A debate was launched regarding the taxation of profits obtained from the digital economy and technical discussions took place concerning the virtual permanent establishment, the collaborative/integrated economy (based on online marketplace platforms - eBay, Uber, Airbnb etc.) and the evaluation of data for tax purposes. 


\section{$\checkmark 26$ September 2017: Tallinn Digital Summit, Estonia}

This event represented a platform for high level discussions regarding the development of plans for digital innovation, with the purpose of enabling Europe to keep up with the evolutions and become a leader of the digital era. The Member States expressed their commitment to change the tax rules worldwide and to adapt their own tax systems in order to make sure that the digital profits inside the European Union are taxed where the value is created.

\section{$\checkmark 19$ October 2017: The conclusion of the European Council}

There is a need for a fair and efficient tax system that is appropriate for the digital era, that leads to a proper payment of taxes by companies and ensures worldwide circumstances for action that are aligned to those adopted by OCDE and other international partners, such as G20.

$\checkmark 3$ December 2017: The project on the conclusions of the Council regarding the taxation of profits obtained from the digital economy

Among other aspects, this document highlights the urgency for an agreement regarding a response of the tax policy for the challenges of the direct taxation of digital economy internationally, as well as the need to adopt an unanimously accepted definition for a permanent establishment and the rules concerning the related transfer pricing and profit allocation. It highlights the principle of tax neutrality, whereby tax policy choices and tax regulations should require a similar treatment for comparable situations.

The project also emphasizes the importance of different data, including the ones of users, for the creation of value by the digital economy in the process of profit generation, and reiterates the need to take into account and evaluate the role of data in the context of the regulations regarding transfer pricing and profit allocation.

\section{$\checkmark 16$ March 2018: The publication of the OECD Interim Report regarding the taxation of the digital economy}

The interim report of the OECD/G20 Inclusive Framework on BEPS is a follow-up to the work delivered in 2015 under Action 1 of the BEPS Project on addressing the tax challenges of the digital economy. It sets out the Inclusive Framework's agreed direction of work on digitalisation and the international tax rules through to 2020. It describes how digitalisation is also affecting other areas of the tax system, providing tax authorities with new tools that are translating into improvements in taxpayer services, improving the efficiency of tax collection and detecting tax evasion.

The measures considered in this interim report include:

- a coherent and simultaneous review of the nexus rules (where to tax) and the profit allocation, essential concepts regarding the allocation of taxing rights between jurisdictions and the determination of the relevant share from the multinational enterprise's profit that will be taxed in a given jurisdiction;

- adopting a provisional measure under the form of an excise tax, applied by the state where certain electronic services are provided, to the gross consideration paid for the provision of these services (proposal that faces opposition from certain states);

- the progress made in the implementation of the BEPS package, with observed effects in cases of multinational companies that have reorganised for tax purposes in order to better align with their economic operations. The impact of implementing the BEPS package on a large scale, together with that of the recent EU directives, as well as some of the matters related to the US tax reform, should lead to the neutralisation of very low effective tax rates for some companies.

$\checkmark 21$ March 2018: New rules proposed by the European Commission for digital taxation - "the digital taxation package"

Two proposals were made:

\section{digital presence \\ 1. Proposal for a Council Directive laying down rules relating to the corporate taxation of a significant}

It introduces the concept of a significant digital presence as an addition to the concept of a permanent establishment and criteria to determine the "digital footprint", such as the revenues obtained from digital services, 
the number of users of digital services or the number of contracts for a digital service. According to these, there is a significant digital presence in a Member State and in a tax period if:

- the revenues from providing digital services to users in that Member State exceed EUR 7000 000;

- the number of users in that Member State exceeds 100 000;

- the number of business contracts for digital services exceeds 3000 in that period.

The profits attributable to a significant digital presence in a Member State are determined based on a functional analysis and will be charged in that Member State based on the national corporate taxation framework.

For this purpose, economically significant activities performed by the significant digital presence, relevant for the development, enhancement, maintenance, protection and exploitation of intangible assets, should be identified, such as:

- the collection, storage, processing, analysis, deployment and sale of user-level data;

- the collection, storage, processing and display of user-generated content;

- the sale of online advertising space;

- the making available of third-party created content on a digital marketplace;

- the supply of any digital service not listed previously.

Attributable profits are determined based on the profit split method, where splitting factors may include expenses incurred for research, development and marketing, as well as the number of users and data collected per Member State.

The provisions apply to entities irrespective of where they are resident of the EU or a third country; however, in the case of the latter, the existence of a convention for the avoidance of double taxation that includes provisions similar to those in the Directive in relation to significant presence and attributable profits is mandatory.

In brief:

\begin{tabular}{|c|c|}
\hline \multicolumn{1}{|c|}{ Where is the tax applied? } & What is taxed? \\
\hline $\begin{array}{l}\checkmark \text { Revenues from providing digital services } \\
>\text { EUR } 7000000\end{array}$ & $\checkmark$ Profits from using data (e.g., advertising space) \\
\hline$\checkmark$ Number of users > 100 000 & $\begin{array}{l}\checkmark \text { Services connecting users (e.g., online } \\
\text { marketplaces, collaborative economy platforms) }\end{array}$ \\
\hline $\begin{array}{l}\checkmark \text { Number of business contracts for digital services } \\
>3000\end{array}$ & $\begin{array}{l}\checkmark \text { Other digital services (for example, streaming } \\
\text { service subscriptions }- \text { such as the content } \\
\text { provided by Netflix or HBO) }\end{array}$ \\
\hline
\end{tabular}

Source: https://ec.europa.eu/taxation_customs/business/company-tax/fair-taxation-digital-economy_en

2. Proposal for a Council Directive on the common system of a digital services tax on revenues resulting from the provision of certain digital services

The Commission presented a proposal for a Directive on a digital services tax (DST), as a simple interim solution for the taxation of digital activities in the EU. DST is a tax on revenues resulting from the provision of certain digital services. The specific objective is to adopt an easy to implement, temporary measure until the introduction of a comprehensive solution. This is in line with the general objectives, which aim:

- to protect the integrity of the Single Market and to ensure its proper functioning;

- to make sure that the public finances within the EU are sustainable and that the national tax bases are not eroded;

- to ensure that social fairness is preserved and that there is a level playing field for all businesses operating in the EU; and

- to fight against aggressive tax planning and to close the gaps that currently exist in the international rules which makes it possible for some digital companies to escape taxation in countries where they operate and create value. 
The tax applies to all entities that meet the following criteria:

- the total amount of worldwide revenues reported by the entity for the latest complete financial year for which a financial statement is available exceeds EUR 750000 000; and

- the total amount of taxable revenues obtained by the entity within the European Union during that financial year exceeds EUR 50000000.

The first criterion limits the application of the tax to large scale companies, which have established strong market positions, allowing them to benefit from network effects and exploitation of big data, and which are able to build their business models around user participation. These entities have the capacity to attract a great number of users, which has a direct effect over the viability of the model. They also have the opportunity of engaging in aggressive tax planning practices, which is why the same threshold has been proposed in other European Union initiatives, such as the CССTB (a Common Consolidated Corporate Tax Base).

How much is the tax?

A 3\% tax rate to be applied on revenues from the following type of services:

\begin{tabular}{|l|l|l|}
\hline$\checkmark$ Online advertising & $\begin{array}{l}\checkmark \text { Selling data collected from } \\
\text { users }\end{array}$ & $\begin{array}{l}\checkmark \text { Digital platforms that facilitate } \\
\text { interaction between users }\end{array}$ \\
\hline $\begin{array}{l}\text { Who will be taxed? } \\
\text { Entities with: }\end{array}$ & $\begin{array}{l}\checkmark \text { A total amount of taxable revenues obtained } \\
\text { within the EU of }>\text { EUR } 50000000\end{array}$ \\
\hline $\begin{array}{l}\checkmark \text { A total amount of worldwide revenues } \\
\text { of }>\text { EUR } 750000000\end{array}$ &
\end{tabular}

The package also includes the communication Time to establish a modern, fair and efficient taxation standard for the digital economy and the Commission Recommendation relating to the corporate taxation of a significant digital presence.

This was followed by a series of other meetings in 2018 and the beginning of 2019, which ended with a compromise text, that is, a proposal for a Council Directive on the common system of a digital advertising tax on revenues resulting from the provision of digital advertising services. Basically, following the ECOFIN discussions during the meeting of 4 December 2018 on this subject, it was decided to analyse the possibility of using an instrument with a narrower scope, that would only include revenues resulting from the provision of digital advertising services - the common system of a digital advertising tax.

The calculation rules are as follows (FISC 135 ECOFIN 242 DIGIT 44 Proposal for a Council Directive on the common system of a digital advertising tax on revenues resulting from the provision of digital advertising services - Political agreement, 1 March 2019, and FISC 151 ECOFIN 277 DIGIT 48 IA 78 Proposal for a Council Directive on the common system of a digital services tax on revenues resulting from the provision of certain digital services, 22 March 2018):

\section{Taxable revenues $=$ Total gross revenues obtained - Value added tax - Other similar taxes}

Taxable revenues should be recognised as obtained at the time when they become due, regardless of whether they have actually been paid by then.

The digital advertising tax should be chargeable in a Member State on the proportion of taxable revenues obtained by a taxable person in a tax period that is treated as obtained in that Member State.

Digital advertising tax chargeable in a Member State $=$ Proportion of taxable revenues obtained in that Member State $\times$ Tax rate

To avoid distortions in the Single Market, there should be a single digital advertising tax rate of 3\% within the EU. 


\section{○ Conclusions}

Currently, there is no consensus between Member States regarding the introduction of this temporary measure to tax digital services. In its absence, states such as France, Italy, Spain, Austria or the Czech Republic are trying to adopt individual solutions which are more or less similar to the provisions in the proposed Directive.

Unilateral measures raise issues in regards to their compatibility with the national legislation of other states, as well as with international rules for the avoidance of double taxation. Their existence might have adverse consequences, that is, they may result in a diversity of rules in the context of the European Single Market.

There is a need to reinterpret the classic permanent establishment concept, in order to ensure a real connection between where the digital profits are obtained and where they are taxed.

Considering that the Council of the European Union was unable to reach an agreement neither for the taxation of digital revenues, nor for the narrower scope alternative for this tax (only for digital advertising services), the EU needs to wait for the international measures agreed by the OECD to be included in the report regarding the international tax system reform in the context of digitalization, which is expected to be completed in 2020.

Considering the availability of the large volume of stored and maintained data (big data), there is a need to improve international cooperation between tax administrations, particularly regarding the information related to online platforms' users, as part of a collaborative economy (sharing economy), to ensure that taxes are paid when they are due.

Unitary, long-term tax measures at international or at least European level have the advantage of a uniform application, with a direct impact over the level of confidence in their effective and fair application.

\section{Bibliography}

1. Campbell, K., Helleloid, D. (2016), Starbucks: Social Responsibility and Tax Avoidance, Journal of Accounting Education, Vol. 37, pp. 38-60.

2. Spirescu, C., Baltac, F. (2018), Impozitarea economiei digitale - cât de curând se va concretiza o astfel de idee?, Tax Magazine, nr. 4, pp. 266-273.

3. OECD (2018), Tax Challenges Arising from Digitalisation - Interim Report 2018. Inclusive Framework on BEPS, available at http://www.oecd.org/ctp/tax-challenges-arising-from-digitalisation-interim-report9789264293083-en.htm.

4. CO EUR 17 CONCL 5 European Council Meeting - Conclusions, 19 October 2017, available at https://www. consilium.europa.eu/media/21620/19-euco-final-conclusions-en.pdf.

5. FISC 135 ECOFIN 242 DIGIT 44 Proposal for a Council Directive on the common system of a digital advertising tax on revenues resulting from the provision of digital advertising services - Political agreement, 1 March 2019, available at https://data.consilium.europa.eu/doc/document/ST-6873-2019-INIT/ro/pdf.

6. FISC 150 ECOFIN 276 DIGIT 47 IA 77 Proposal for a Council Directive laying down rules relating to the corporate taxation of a significant digital presence, 22 March 2018, available at http://data.consilium. europa.eu/doc/document/ST-7419-2018-INIT/ro/pdf.

7. FISC 151 ECOFIN 277 DIGIT 48 IA 78 Proposal for a Council Directive on the common system of a digital services tax on revenues resulting from the provision of certain digital services, 22 March 2018, available at http://data.consilium.europa.eu/doc/document/ST-7420-2018-INIT/ro/pdf.

8. FISC 320 ECOFIN 1064 Council Conclusions on "Responding to the Challenges of Taxation of Profits of the Digital Economy", 30 November 2017, available at https://data.consilium.europa.eu/doc/document/ST15175-2017-INIT/en/pdf.

9. https://ec.europa.eu/taxation_customs/business/company-tax/fair-taxation-digital-economy_en

10. https://www.consilium.europa.eu/ro/policies/digital-taxation/ 